\title{
ON THE ORIENTAL CULICID GENUS LEICESTERIA, THEOBALD.
}

\author{
By F. W. Edwards, B.A., F.E.S.
}

(Published by permission of the Trustees of the British Museum.)

The genus Leicesteria was founded by Theobald in 1904 (Entomologist, xxxvii, p. 211) for a species" of mosquito found by Dr. G. F. Leicester in the Malay States, the most remarkable character of which was the great length of the female palpi, a condition known otherwise among the Culicidae only in Anopheles, Megarhinus and Mucidus, all genera to which the new species was obviously unrelated. Subsequently Dr. Leicester" placed on record his discovery of four other species essentially similar to Theobald's Leicesteria longipalpis; for one of these he created the new genus Chaetomyia. Additional species referable to the genus have since been described by Theobald. $\dagger$

The present contribution is based mainly on an examination of Dr. Leicester's fine collection, which he has recently presented to the British Museum; a study of this has revealed the existence of three undescribed species, descriptions of which are herewith presented. Through the courtesy of Dr. N. Annandale and Mr. F. H. Gravely of the Indian Museum I have also been enabled to make a detailed examination of the types of Leicesteria apicalis, Theo., and Brevirhynchus apicalis, Theo.; I am therefore in a position to offer a thorough revision of the species of this interesting genus. The very clear drawings of male genitalia have been made for me by my wife from balsam preparations. It should be noted that the basal parts are represented as transparent in order to show the unci.

\section{Characters and systematic position of the genus.}

Adult characters.-Eyes very narrowly separated. Proboscis thick, shorter than the abdomen, very slightly swollen at the apex. Male antennae plumose. Palpi of female at least half as long as the proboscis, three-jointed, the elongation occurring mainly in the second joint, terminal joint minute; palpi of male longer than the proboscis by the last joint, thin, without hair-tufts, the last two joints curved upwards. Prothoracic lobes well separated, and more or less retracted under the mesonotum which is arched forwards over the head. Scutellum obviously trilobed. Postnotum $\ddagger$ without setae (except in L. flava). Front

* Studies from Inst. for Med. Research, Fed. Malay States, iii, pt. 3, pp. 94-100 (1908).

† Rec. Ind. Mus. ii, 1908, pp. 291-294

+ Following Dyar and Knab, the writer replaces the term "metanotum " by "postnotum," since the structure indicated is really part of the mesothorax and not of the metathorax.

(32926-2.) Wt. P 12-42. 1000. 2/14. D\& S. 
tibiae shorter than the others (except in L. fava, in which the hind pair are the shortest). Hind tibiae provided with a distinct scraper at the tip. Front claws of male unequal, one or both toothed; middle claws equal or almost so, toothed; front and middle claws of female equal, toothed. Wings of the normal Culicid type, without any distinctive feature. Male genitalia : the side-pieces have welldeveloped basal lobes, which bear spines, but the lobes are not sufficiently divided off from the side-pieces to be regarded as true harpagones; clasp-filament with 5-9 apical or subapical spines; unci with slightly crenulate margins. Female abdomen tapering; eighth segment very large and not at all retractile. Head, and scutellum clothed with broad flat scales. Except in the doubtful $L$. annulipalpis, the colouring is of uniform type throughout the genus. The covering of the thorax is brown, narrowly creamy on the borders; the abdominal scaling is brown above, with large white lateral patches on each tergite.

Larval characters.-Nothing has been recorded concerning the larvae, beyond the fact that they live in bamboos. I have so far been unable to obtain any specimens through correspondents for purposes of description.

Systematic position.-The genus doubtless belongs to the Aëdes group of the Culicini, in spite of the fact that one of the species, in having short hind tibiae and setae on the postnotum, exhibits two otherwise exclusively Sabethine characters. This species (L. flava), however, cannot be separated from the genus, as in all other respects, especially in its male genitalia, it conforms to the generic characters of Leicesteria; its Sabethine characters should probably, therefore, be regarded as evidence of reversion to an earlier type. The nearest relative of Leicesteria is evidently Armigeres (= Desvoidya), which differs only as follows: the female palpi are much shorter; the mesonotum is not distinctly produced over the head; the male genitalia have much more numerous spines on the clasp-filament, and the basal lobes of the side pieces are not so well developed. The two genera together form a distinct division of the Aëdes group, distinguished by the peculiar structure of the male genitalia and (probably) by the structure and habits of the larvae, those of Armigeres being carnivorous and having neither hair-tuft nor pecten on the siphon-tube. Whether the two genera will ultimately have to be united cannot at present be decided.

The following synonymy may be given for the genus :

\section{Leicesteria, Theo.}

\section{Entomologist, xxxvii, p. 211 (1904).}

Chaetomyia, Leic., Cul. of Malaya, p. 100 (1908).

Brevirhynchus, Theo., Rec. Ind. Mus. ii, p. 293 (1908).

Leicesteriomyia, Brun., Rec. Ind. Mus. iv, p. 452 (1912) (nom. n. for Chaetomyia).

Brevirhynchus is in all respects similar to Leicesteria ; Theobald had apparently forgotten the existence of the latter genus when redescribing it under a new name. 


\section{Key for determining the Species.}

1. Female with simple claws; the palpi with a white ring in the middle ; all joints of hind tarsi with distinct basal white rings annulipalpis, Theo.

Female with toothed claws on the front and middle legs; female palpi without white ring in middle; if the hind tarsi have pale rings these generally embrace both ends of the joints ... ...

2. Hind tibiae distinctly shorter than the front ones; postnotum with a few setae or scales or both $\quad \ldots \quad \quad \ldots \quad \quad \ldots$ flava, Leic.

Hind tibiae slightly longer than the front ones; postnotum bare

3. Abdominal segments 4-7 with basal lateral yellow patches, in addition to the more apically placed white ones; hind tarsi with more or less distinct pale rings

Abdominal segments 4-7 without lateral yellow patches; hind

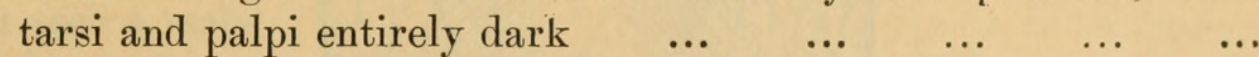

4. Clypeus bare ; female palpi all dark; thorax much produced over

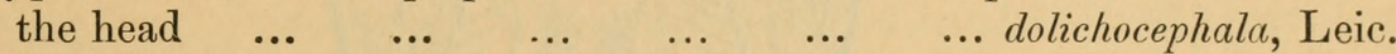

Clypeus more or less scaly; female palpi with the extreme tip white ; thorax not so much produced $\ldots$... $\quad . . \quad \ldots$

ellowish median basal patches on abdominal segments 3-8 or $5-8$; the white lateral patches on segments 6 and 7 not quite reaching the hind margins...

... magna, Theo.

No yellowish median basal patches on abdominal segments; the white lateral patches on segments 6 and 7 reaching the hind

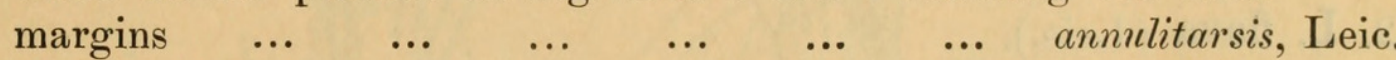

6. White lateral abdominal patches produced over the dorsum at or

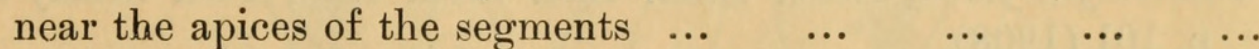

White patches not at all produced over the dorsum, which is all blackish

7. The lateral abdominal patches become creamy towards the dorsum, where they form narrow but complete apical bands

cingulata, Leic.

The lateral abdominal patches do not become creamy dorsally, do not quite meet in the middle line, and do not quite reach the

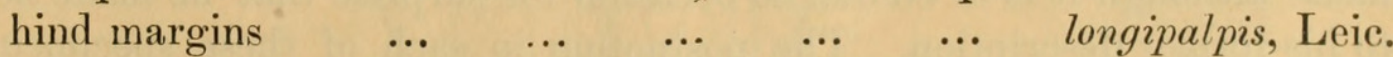

8. White lateral abdominal patches with their upper edges straight; hind metatarsi distinctly shorter than the tibiae pendula, sp. n.

White patches with their upper edges markedly concave; hind metatarsi and tibiae about equal in length

9. Smaller ; female palpi two-thirds as long as the proboscis

Larger ; female palpi only half as long as the proboscis

digitata, sp. n. pectinata, sp. n.

1. L. annulipalpis (Theo.).

Brevirhynchus annulipalpis, Theo., Rec. Ind. Mus. iv, p. 6 (1910).

I have not examined the type of this species, and feel some doubt whether it really belongs here, as the type of marking appears to be quite different from 
that of all the other species, besides which the claws are said to be all simple. Until the male is known however it can only be placed in this genus.

Described by Theobald from a single female from Travancore (Maddathoray).

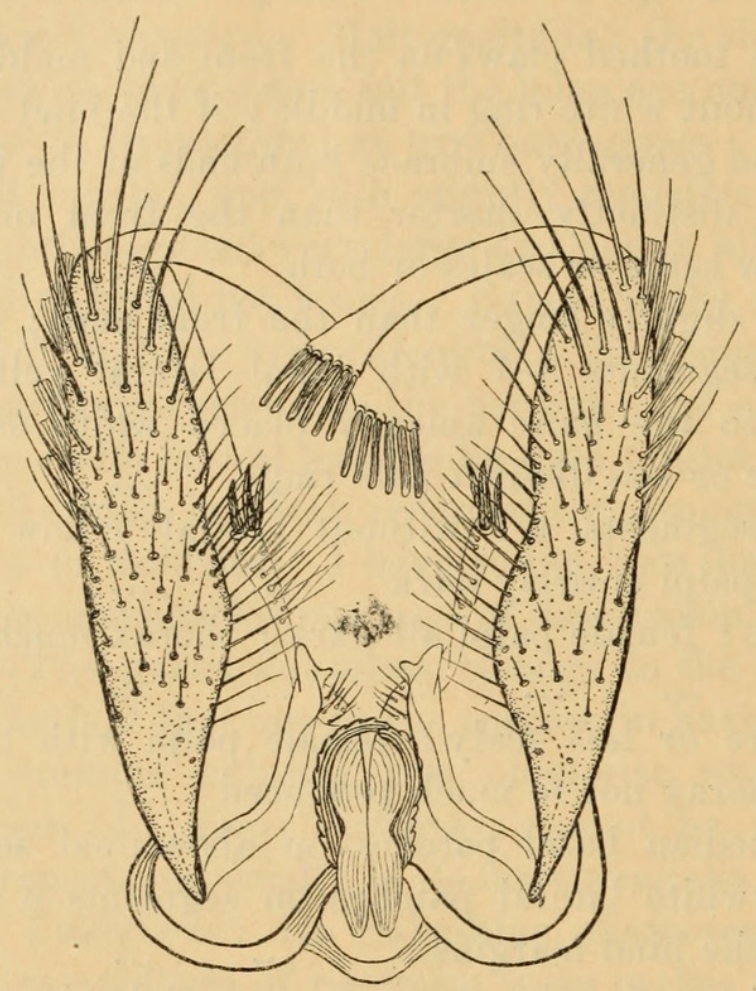

Fig. 1.-Male genitalia of Leicesteria flava, Leic.

2. L. flava (Leic.).

Chaetomyia Aava, Leic., Stud. Inst. Med. Res., Fed. Malay States, iii, p. 101 (1908).

Leicesteria apicalis, Theo., Rec. Ind. Mus. ii, p. 291 (1908).

Brevirhynchus apicalis, Theo., Rec. Ind. Mus. iv, p. 7 (1910).

I have compared the male and female types of Leicesteria apicalis with the female type of Brevirhynchus apicalis and with three female cotypes of Chaetomyia fava; they undoubtedly all belong to the same species, and it is somewhat curious that Theobald should have redescribed $L$. apicalis under the same specific name although it is of course no occasion for surprise that he made no reference to his former description. The postnotum in each of these specimens bears at least two or three small pale hairs, while Leicester's specimens have some scales in addition. L. apicalis $\bigcirc$ was described as having the integument of the thorax "shiny black"; this is quite incorrect, it is rather light brown (even in the type) as in other species of the genus. The middle legs of the male type are missing, hence probably Theobald's statement that the middle claws are unequal was pure assumption ; they are equal in the Sarawak male as in all the other species I have examined. I made a preparation of the genitalia of the male type of $L$. apicalis and found that they corresponded in almost every detail with those of the specimen figured (from Sarawak); there were however five instead of six apical spines to the claspers. In both the males examined the basal lobes of the side-pieces bore three spines. 
A part from the tibial characters, L. flava much resembles $L$. cingulata, from which it can easily be distinguished by the narrow pale rings on the tarsi and the yellowish rings on the male palpi.

Malay States ; Assam ; Sarawak (J.Hewitt, 10 10 in Cambridge Museum).

\section{L. dolichocephala, Leic.}

Leicesteria dolichocephala, Leic., op. cit. p. 95.

It is a little difficult to be certain whether the hood-like appearance of the thorax is entirely natural, or whether it may not be partly due to the head having shrunk. The pale rings on the hind tarsi are much fainter than in the two following species and may be quite absent ; the dorsum of the abdomen, as in L. annulitarsis, is entirely dark, except for a yellowish patch on the eighth segment; the white patch on the second abdominal segment is more oblique than in the next two species. The British Museum possesses four female cotypes; I have not seen a male.

Recorded only from near Kuala Lumpur, Federated Malay States.

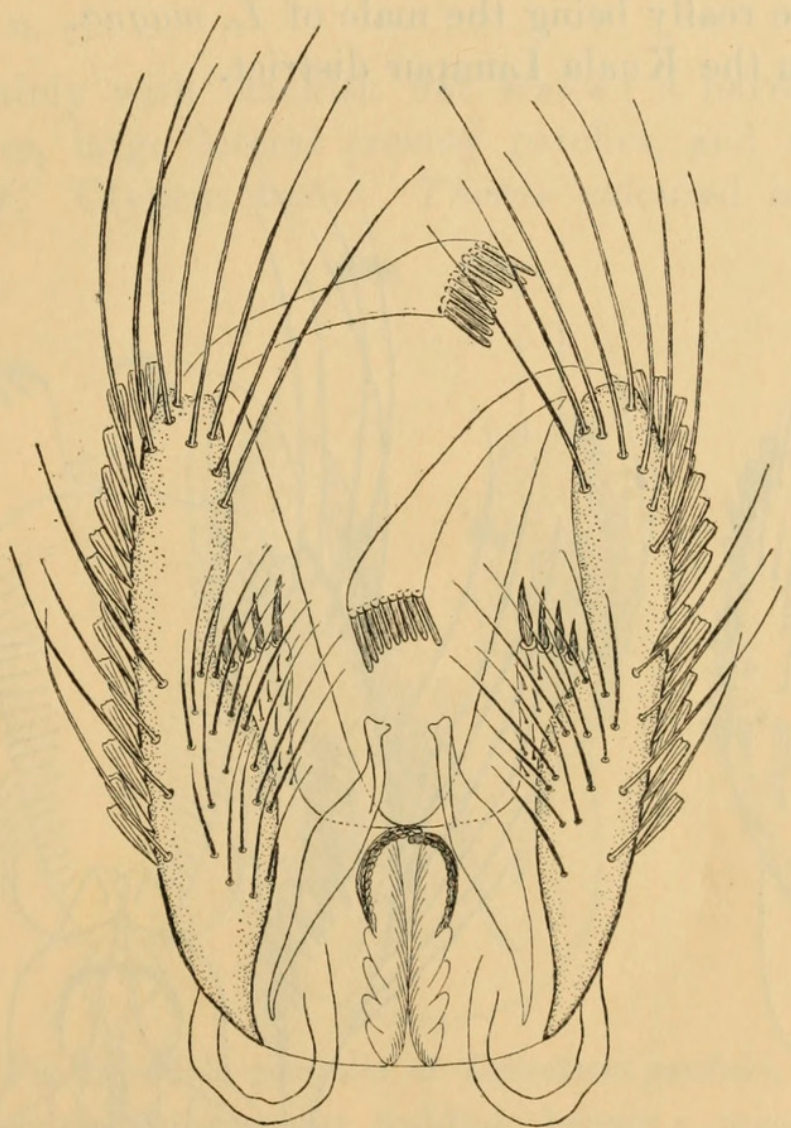

Fig. 2.-Male genitalia of Leicesteria magna, Theo.

4. L. magna (Theo.).

Brevirhynchus magnus, Theo., Rec. Ind. Mus. ii, p. 293 (1908).

Leicesteria annulitarsis (ô only), Leic., op cit, p. 100 (1908).

Toxorhynchites rectirostris (Giles MS.), Theo., Mon. Cul. v, p. 214 (1910) (nom. nud.).

The characters given in the key should facilitate the recognition of this species. It is rather larger than $L$. annulitarsis and the tips of the female palpi are not so 
conspicuously white. The male genital claspers terminate in a comb consisting of nine blunt-ended teeth and the basal lobes of the side-pieces bear four teeth in a single row.

Dr. Leicester had apparently not distinguished this species from the next.

Assam; Travancore ; Sukna; Philippine Islands (1 O, Lt. E. R. Whitmore, presented to the British Museum by Col. Giles); Federated Malay States : Ulu Klang and near Kuala Lumpur (1 $\delta^{\star} 2 \%$ in British Museum in Dr. Leicester's collection).

\section{L. annulitarsis, Leic.}

Leicesteria annulitarsis, Leic., op. cit. p. 99.

Apart from the characters already noticed, this species seems to differ from L. magna in the possession of long lateral scales on the whole of the second vein ; in the latter species the base of this vein appears to be without lateral scales, but this may possibly be due to denudation. There are four females in the British Museum in Dr. Leicester's collection, but the male is at present unknown, Leicester's single male really being the male of $L$. magna.

Recorded only from the Kuala Lumpur district.

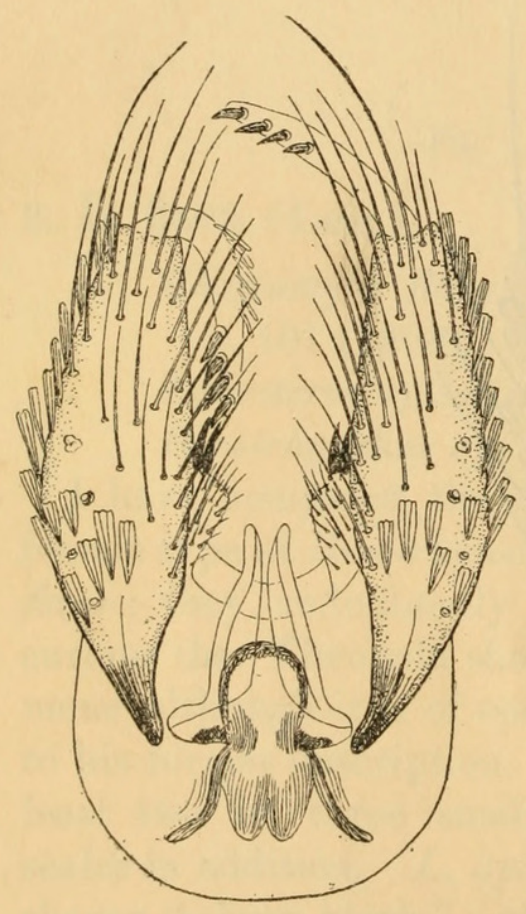

Fig. 3.-Male genitalia of Leicesteria cingulata, Leic.

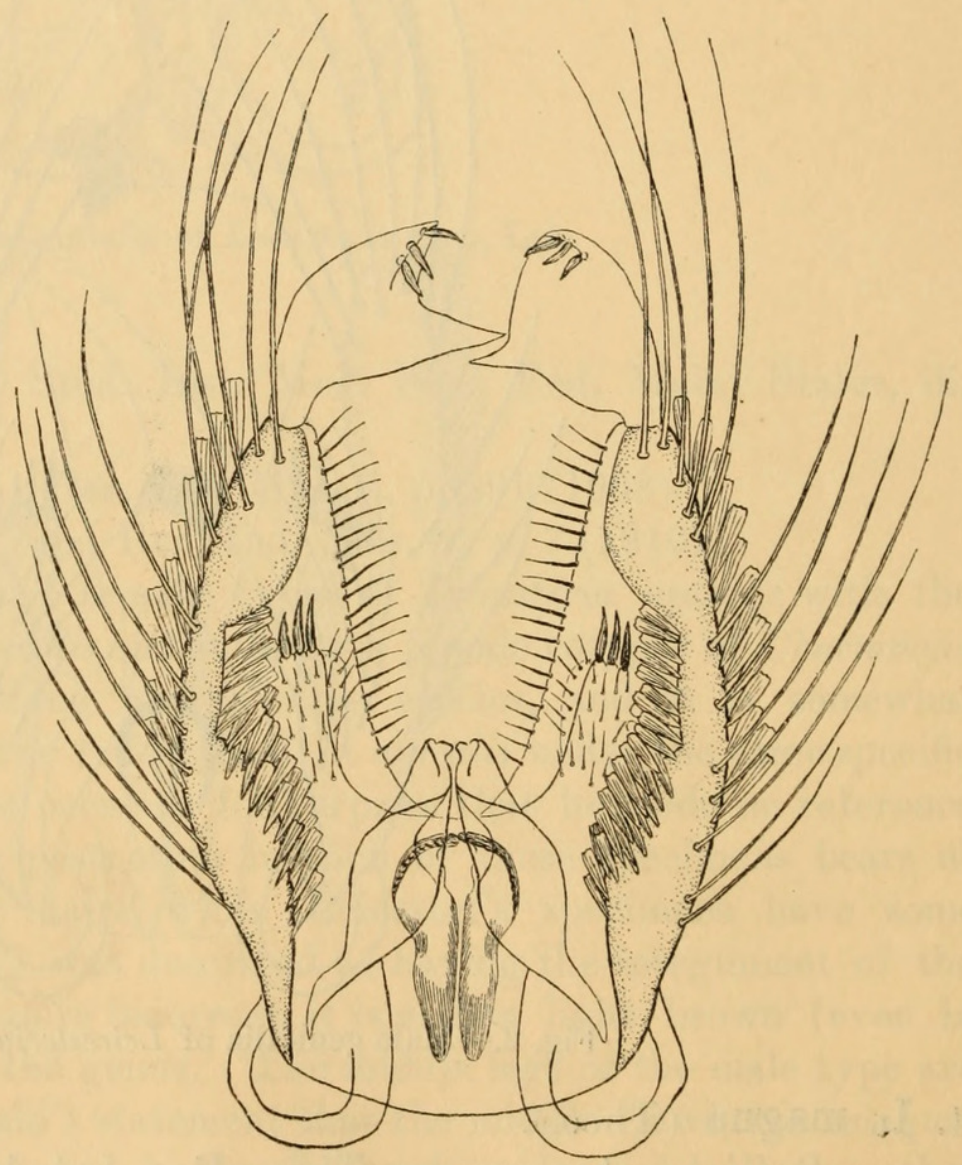

Fig. 4.-Male genitalia of Leicesteria longipalpis, Leic.

6. L. cingulata, Leic.

Leicesteria cingulata, Leic., op. cit. p. 97.

The three specimens ( $1 \sigma^{\star} 2$ O ) in the British Museum have no scales on the clypeus; they are labelled "The Gap. At the edges of a stream in the jungle. 
16.iv. 04." The basal lobes of the male genitalia bear two teeth ; the claspers have four teeth placed rather far apart, and also on the opposite side a row of scales.

Recorded only from the Kuala Lumpur district.

\section{L. longipalpis, Leic.}

Leicesteria longipalpis, Leic., Entomologist, xxxvi, p. 211 (1904).

This species is represented in the British Museum by the type male (from which the accompanying drawing was taken), the type female and one other female. The male genital claspers are much broader than in any other species and, in addition to the three chitinous teeth, are provided with a large membranous projection; the basal lobes of the side-pieces bear three teeth and the side-pieces themselves have a large paich of scales which seem to project inwards.

Known definitely only from the Kuala Lumpur district.

\section{L. pendula, sp. n. $\overbrace{}^{\top}$.}

Head clothed mainly with blackish flat scales; a narrow border of creamy ones round the eyes, large lateral creamy patches, and a small patch in the middle also creamy. Clypeus bare. Thorax coloured much as in the other

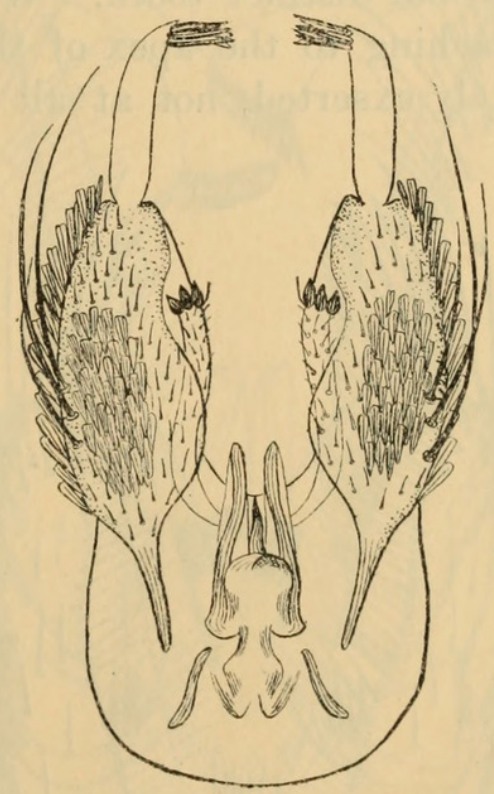

Fig. 5.-Male genitalia of Leicesteria pendula, Edw.

members of the genus: integument reddish brown; mesonotum clothed with dark brown narrow scales, with a narrow border of creamy ones; scales on pleurae and prothoracic lobes whitish, those on scutellum dark brown. Legs with scales all dark brown, except those on the undersides of the femora, which are whitish. Front tibiae markedly shorter than the middle and hind ones; all the tibiae noticeably longer than the corresponding metatarsi; the last three joints of the middle tarsi are (in the dried specimens) bent backwards. Front claws very unequal; the larger one with a single tooth near the base, the smaller simple. Middle claws equal, rather small, each with a slight thickening 
near the base which cannot be called a tooth. Hind claws very small, equal and simple, nearly straight. Wings shorter than in any of the other species; if extended backwards they only reach to the base of the sixth abdominal segment. First fork-cell longer than second, their bases almost level. Abdomen dark brown; first segment with a white lateral patch; second to seventh with large white lateral triangular patches, their apices not quite reaching the apices of the segments; as in the other species these patches are diagonally placed. Genitalia very small, completely exserted and pendulous (whence the specific name). Claspers with five teeth arranged in a bunch at the apex. Side-pieces with a large scale patch on the ventral side; their basal lobes bear three teeth and also a fine hair. The genitalia are much less hairy than in the other species.

Length of body (without head) $6 \mathrm{~mm}$.; of wing $4 \mathrm{~mm}$.

Described from a type male and three other males in Dr. Leicester's collection in the British Museum, labelled "Edges of stream in jungle. The Gap. 16. iv.04.” (Dr. G. F. Leicester.)

9. L. digitata, sp. n. $\delta$ ९.

Differs from $L$. pendula as follows: White patches of abdomen less pointed, and with their upper or anterior edge somewhat concave, especially in the female. Hind metatarsi of the male almost as long as the tibiae. Middle claws of the male each with a small but distinct tooth. Wings a trifle longer than in L. pendula, those of male reaching to the apex of the 6th abdominal segment. Genitalia not quite completely exserted, not at all pendulous and much more

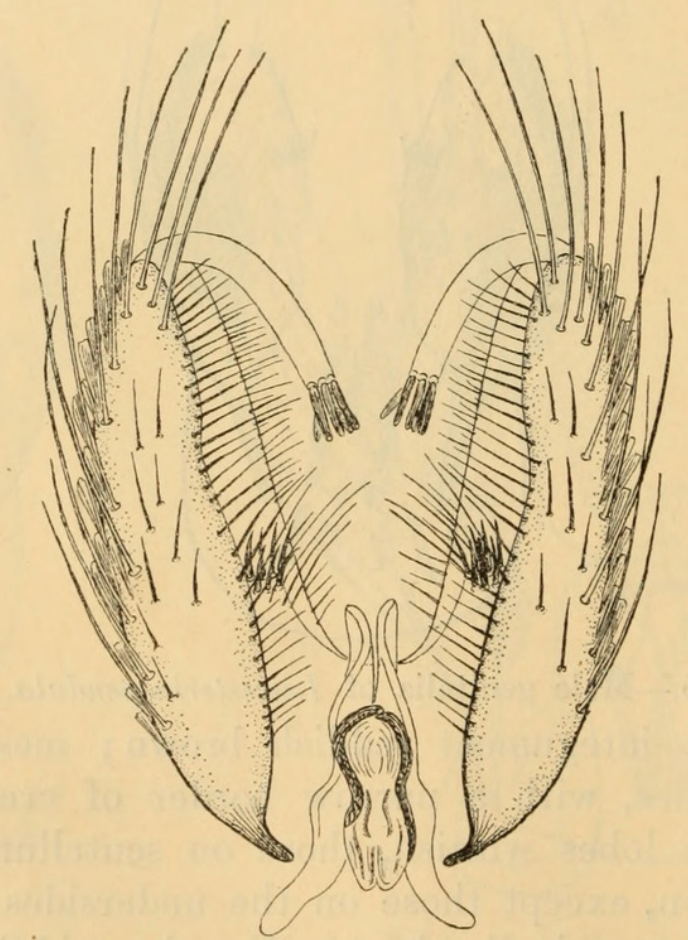

Fig. 6.-Male genitalia of Leicesteria digitata, Edw.

bristly. The claspers bear five terminal spines which are less pointed than in L. pendula and are arranged something like the spread-out fingers of a hand. The basal lobes of the side-pieces have seven sharp spines which, when seen from certain directions, appear to be arranged in two rows. Female palpi quite two-thirds as long as the proboscis. 
Length of body (without head) about $4 \mathrm{~mm}$.

The following specimens are in the British Museum: Type and one other male and one female, bred from larvae in bamboo, Ulu Gombak, Federated Malay States, 28. viii. 03 and 2. ix. 03 (Dr. C. W. Daniels); 2 Q, at edges of stream in jungle, The Gap, 16.iv.04 (Dr. G. F. Leicester) ; 1 of 1 o, Pahang Road jungle, 6 miles from Kuala Lumpur, 4. iv. 03 and 18.x.03 (Dr. G. F. Leicester) ; 1 o 2 o, Mailum Negros, Philippine Islands, 9. vi.06 (C.S. Banks ; identified by the collector as L. longipalpis).

10. L. pectinata, sp. n. $\delta$.

Differs from $L$. digitata only as follows: Rather larger $(5 \mathrm{~mm}$.) ; female palpi shorter, scarcely more than half the length of the proboscis. Male genitalia: the claspers terminate in a comb-like row of nine teeth; the basal lobes of the side pieces each carry two separate pairs of teeth.

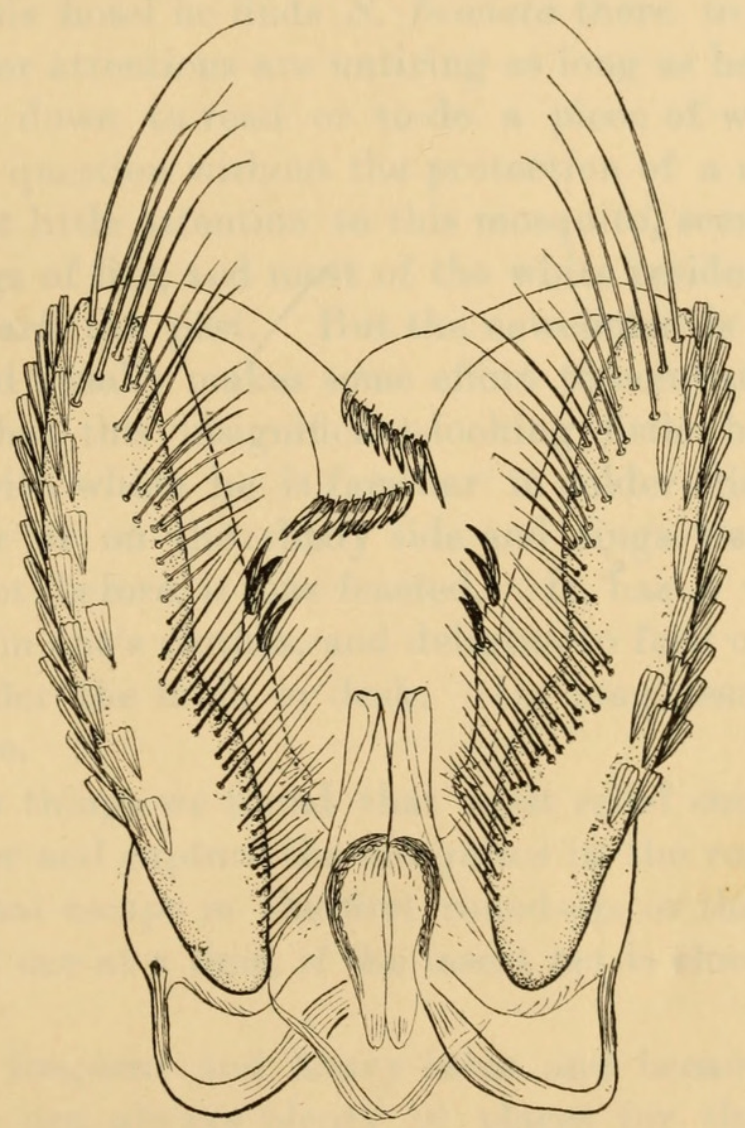

Fig. 7.-Male genitalia of Leicesteria pectinata, Edw.

Type male and one female bred from larvae (?) in leaf in jungle, 3-7.ix. 04, at Jugra, Federated Malay States (Dr. G. F. Leicester). A second male (the one figured) is unlabelled, but looks as though it may have belonged to the same lot. There is a female in the Cambridge Museum from Sarawak ( $J$. Hewitt). 


\section{$2 \mathrm{BHL}$ Biodiversity Heritage Library}

Edwards, F W. 1914. "On the Oriental Culicid genus Leicesteria, Theobald." Bulletin of entomological research 4, 255-263.

https://doi.org/10.1017/s0007485300043182.

View This Item Online: https://www.biodiversitylibrary.org/item/110754

DOI: https://doi.org/10.1017/s0007485300043182

Permalink: https://www.biodiversitylibrary.org/partpdf/118023

\section{Holding Institution}

Smithsonian Libraries

\section{Sponsored by}

Biodiversity Heritage Library

\section{Copyright \& Reuse}

Copyright Status: Public domain. The BHL considers that this work is no longer under copyright protection.

This document was created from content at the Biodiversity Heritage Library, the world's largest open access digital library for biodiversity literature and archives. Visit BHL at https://www.biodiversitylibrary.org. 